\title{
ROYAL APOTHEGARIES OF THE TUDOR PERIOD
}

\author{
by
}

\section{LESLIE G. MATTHEWS}

FROM the time when the practice of pharmacy became recognized as something apart from medicine and surgery a skilled person was needed to procure drugs and make up the medicines prescribed. To ensure the best possible service the monarchs of this country engaged the most skilled physicians, surgeons and apothecaries obtainable. The Tudors were no exception.

Little information is available about the Royal apothecaries employed during the reign of Henry VII (1485-1509). On 25 October 1488, John Grice (or Gryce) was awarded an annuity for life of $f_{10}$ as King's apothecary, dating from Michaelmas $1488,{ }^{1}$ and three days later John Pykenham, styled the King's servant, was granted a similar annuity for life as apothecary to Henry's Queen, Elizabeth of York, ${ }^{2}$ from which it seems likely that Grice superseded Pykenham in the royal favour. Grice was well rewarded for his services to his king. No less than seven grants of houses and lands were made to him between the years 1497 and I500; six of these are listed in the Patent Rolls, all of them in the City of London: the seventh grant is obliquely referred to when the property, a tcnement in the parish of St. Margaret Pattens, is given to two yeomen 'of the King's "le Picherhouse" ', the well house, after the death of Grice in $1505 .{ }^{3}$

Grice must have been a wealthy man. The lands and houses were all well situated in streets known to have been the abode of drapers, grocers and apothecaries: two of them were inns, the Dolphin and the Lamb, and they would have brought him a considerable income from rents. Like later apothecaries in the service of the Tudor monarchs, Grice was also serjeant of the King's Confectionary. Part of his duties may have been to supervise the preparation of the many 'dragees' and sweetmeats which were customarily provided for the royal household. Though we are without definite record, it seems likely that Thomas Pierson was appointed apothecary to Henry VII to succeed Grice for Pierson is the first apothecary mentioned in the King's Book of Payments of I July I 509. Henry had died on 2 I April of that year. Pierson is noted as having received $£_{13} 6 s$. $8 d$. (20 marks), probably half a year's salary. ${ }^{4}$

The sixteenth century saw the beginnings of ordered regulation of the practice of medicine in England: this in turn had a considerable influence upon pharmacy. Prompted by Thomas Linacre (1460-1524), Henry VIII, early in his reign (1509-47) assented to the Medical Act of 1512 and granted a Charter to the College of Physicians of London, later the Royal College. In I540 he approved an Act by which two Companies of the City of London, the Barbers and the Surgeons, were incorporated into one body. The well known painting, designed if not executed by Holbein himself in $154^{1}$, depicting Henry VIII in the act of handing a Charter to Thomas Vicary-possibly the Barbers' Charter 


\section{Royal Apothecaries of the Tudor Period}

of 1462 was taken from the strong box for the occasion-includes portraits of the leading physicians and surgeons of the day. The group includes Thomas Alsop, the King's apothecary. He appears as the last figure on the right of the king. Tall, good looking, with oval face and hazel-eyed, Alsop would have attracted attention in any company. He wears a fur-edged robe and a gold chain, perhaps a gift from his royal master.

Henry VIII's personal interest in pharmacy is exemplified by the many recipes for plasters, ointments, etc., attributed to him and recorded in a Sloane MS. in the British Museum-No. 1047. These recipes were described by Blaxland Stubbs (193I) in his paper, 'Royal Recipes for Plasters, Ointments and other Medicaments' ${ }^{5}$ Whether they were actually devised by Henry or were given his blessing after personal trial is still uncertain. The Letters and Papers of his reign give the names and some particulars of the appointment of his many apothecaries, their remuneration and the Royal benefactions to those who gave faithful service. In I93 I Howard Bayles illustrated and commented upon the medicines supplied by Thomas Alsop in I 546-7, the details being taken from the lengthy original bills to be found in the Public Record Office. Bayles also mentioned two other royal apothecaries, John de Soto and John Emmyngwey. ${ }^{6}$ Thomas Alsop's accounts, referred to below, show the great variety of medicaments, perfumes and spices, including those for Henry VIII's funeral and those to be put into the lead coffin, which an apothecary of his standing was expected to prepare and supply.

Thomas Pierson, mentioned above, had acted as apothecary to the 'Princess of Castile' in 1509 and had received $40 s$. $2 \frac{1}{2} d$. as payment of sixty-three days' wages for his services, the physician who attended the Princess having the generous sum of $£_{1} 100$ paid in gold. ${ }^{7}$ In ${ }_{15} 16$ Pierson was exempted from serving on juries. From comparable records of the City of London this was not unusual when a man was getting on in years. In that year too Richard Babham was appointed apothecary for life to Henry VIII with a yearly salary of $£$ Io, presumably replacing Pierson. ${ }^{8}$ Babham had been a member of the Grocers' Company for some years. He had already been in the service of Henry VII though only for a short time. There is evidence of this by his having a mourning gown with hood for Henry VII's funeral and by the payment to him in 15I5, six years after Henry VII's death, of $£ 18$ Ios. od. for 'certain things laid out by him for King Henry VIII'.

Babham must have continued without a break, though his formal appointment is not recorded until $15 \mathrm{I} 6$, for he is listed as of Henry VIII's household and is described as 'Serjeant of the Confectionary' at the Coronation of Henry VIII and Queen Catherine in 1509 when he and two others of the Confectionary received a number of yards of scarlet and red cloth for suitable robes for the occasion. ${ }^{10}$ Pierson does not fade out completely: he continued to supply some members of the Court with medicines and at Wolsey's death in 1530 he was owed $£^{8} 4 s$. $5 d$. for medicines and confections supplied to the late Gardinal. ${ }^{11}$ He was a warden of the Grocers' Company in $1530-1$. His heirs were tenants of a property near 'Le Rose', perhaps the inn of that name in Fleet Street. London, in $15^{88.12}$ 


\section{Leslie G. Mattherws}

It was most likely Babham who in $15^{18}$ submitted an account to the 'Gardaroba', where the King's personal household accounts were kept, for materials supplied to the royal household-sugar, rosewater and various spices, the list including 'socate' (? socatrine aloes) 4 lb. $2 s .8 d$., and 'lozenges, gilt' $3 \mathrm{lb}$. for IOs. ${ }^{13}$ Babham was one of the staff of the household who attended Henry VIII at his meeting with the French king, known as the 'Field of the Cloth of Gold', in $1520 .{ }^{14}$ His payment of $f$ ro a year for life is again recorded in that year and he was allowed livery regularly. ${ }^{15}$ Master John de Soto, apothecary, attended upon the Queen.

At the end of 1519 a new name comes in-Cuthbert Blackeden (or Blagdon) as yeoman apothecary. This was the rank of assistant apothecary. He, too, was a member of the Grocers' Company of London. His wages in $15^{19}$ and in 1520 were 22s. Iod. each quarter. ${ }^{16}$ Blackeden was evidently regarded as likely to succeed Babham and in fact he did take Babham's place and received an annuity of $£ 10$ a year when Babham died in 1527.17 The Confectionary, for tax purposes, was as important as the Royal Cellar and both were assessed for the subsidy at $£ 100 .{ }^{18}$ The Serjeant of the Confectionary, in common with others of his standing, received the 'Bouche de Court', the customary allowance made to senior servants. The 'Bouche' entitled him to bread, ale and wine and, according to the season of the year, torches, pricketts, faggots and coal. When the apothecary was in attendance on his Majesty he was to have his lodging in the King's house 'when he repaired to it'. ${ }^{19}$ Blackeden had instructions to 'attend upon the Queen's Grace', Anne Boleyn, at her Coronation on 29 May $1533:{ }^{20}$ he must have looked a fine figure of a man when, in 1538 , he had his share of 'stuffe delivered out of the Tower', namely, cloth of silver, tissue, velvet and satin for a doublet. ${ }^{21} \mathrm{~A}$ year earlier he, with other servants, had been given some of the gold brooches that had belonged to the late Queen, Jane Seymour. Blackeden died in 1540; a small brass commemorating him was placed in Thames Ditton Church, Surrey, by his wife Julia in 1580 (see plate opp. p. 186 ).

By 1540 Thomas Alsop had become chief apothecary to Henry VIII with the title of 'Gentleman Apothecary'. Alsop was paid $£^{6}$ I 3 s. $4 d$. (Io marks) each quarter. ${ }^{22}$ His accounts, already mentioned, are a valuable commentary on the practice of pharmacy in the middle of the sixteenth century. They cover the six months August 1546 to January 1547, the month in which Henry VIII died. ${ }^{23}$ The bills for the last five months were unusually large as the king was then needing all the attention his physicians and surgeons could give him. From about $£ 5$ in August the bill went up to $£ 25$ in December, though not all the medicines and perfumes were for Henry himself. Fomentations, plasters, sponges and applications for the stomach and 'ventrum' are furnished for use by the surgeons, in addition to decoction of guaiacum, gargles, and on many occasions, dragees and cumfyttes of aniseed and of sweet fennell and, almost at the last, a syrup of 'bizanciis'. Alsop had also to supply liquorice and sugar for the king's hounds, and for the hawks, horehound water, rhubarb and mummy, pills for hawk casting, the 'first water' for washing their meat, gum tragacanth and sugar candy. Details are given of the medicines, etc. for 'My Lady Mary's Grace' and for 'Lady Margret Duglas': amongst other things she had '2 glases 


\section{Royal Apothecaries of the Tudor Period}

with aqua lactis virginis', a dilute benzoin tincture, for the morphew, a term generally used to denote a scurvy eruption. The whole account totalled $£ 1273^{5.2 d}$. for the six months and Edward VI paid the first $£ 100$ at the end of May in the same year it was submitted (1547) and the balance at the end of June. Henry VIII did not forget Alsop's services: under his will Alsop received 100 marks ( $f 66$ I $3 s .4 d$.). ${ }^{24}$

Alsop, described in the records of the City of London as 'Grocer', became a Warden of the Grocers' Company in 1552-3 and remained a member of their Court of Assistants until $1557 .{ }^{25}$ Most apothecaries in London were at that time members of the Grocers' Company, though a distinct section of it: not until I6I 7 were they able to separate from the Grocers and form their own Company or 'Society of Apothecaries of London', as they are more correctly styled. He profited, as did many of the servants of Henry VIII, when lands and houses belonging to monasteries and other Church establishments were sequestrated under the Act of 1537 . In 1539 we find him and his wife Anne paying $£ 285$ for a grant of eight tenements in the parish of St. Stephens, Walbrook, London, all of which had belonged 'to the late house' (or College) of St. Thomas of Acon. ${ }^{26}$ One of these tenements was 'le Barge', a large house of stone and wood, which, according to Stow, was sited where barges in which goods were rowed up the Walbrook from the Thames were unloaded. Alsop died on 16 January $155^{8}$ and at the Inquisition Post Mortem on his estate two months later, these properties were enumerated and reference was made to his service to his king. The properties carried the obligation of the twentieth part of a knight's service (then commuted for cash) and yearly rent of $55^{5}$. Alsop held other important properties in the City of London, in Deptford and in Greenwich. Their annual value was assessed at the Inquisition at $£ 55$, a considerable estate at that time. By his will he left his wife a life interest, with reversion to his nephews and to his wife's son by a former marriage. ${ }^{27}$

The number of the apothecary staff was increased in $154^{\circ}$ and again in $154^{6}$. John Hemingway (sometimes Emmyngwey) who had been apprenticed to Blackeden in $153^{128}$ was appointed yeoman apothecary some time before 1542 and a Patrick Reynolds was engaged from Michaelmas 1546 as an additional apothecary to Henry VIII, at a salary of 40 marks a year. ${ }^{29}$ Reynolds was a subscribing witness to Henry VIII's will and, like Alsop, had a legacy from the king of 100 marks. ${ }^{30}$ Both Reynolds and Alsop continued as apothecaries to Edward VI (reigned I547-53) but Reynolds died early in 1551. In October of that year there is noted a grant for life 'to the King's servant John Hemingway for services to the King's father, Henry VIII, of the office of King's apothecary vice Patrick Reynolds, deceased, with wages of 40 marks yearly payable at the Receipt of the Exchequer from Midsummer last, quarterly'.31 During Edward's reign Alsop retained the title of Serjeant of the Confectionary. The fact that Edward VI was an ailing child at the time he came to the throne probably accounted for the appointment of a third apothecary, George Carlton, at Christmas, 1546 , at the usual salary of 40 marks a year, ${ }^{32}$ so that there would always be at least one apothecary available to provide the medicines required. At Edward's death in 1553 a complete list of the household staff was made, the 


\section{Leslie G. Mattheres}

purpose being to determine the number of yards of 'Blakcloth' for Court mourning that Queen Mary would have to provide. Each page of the list is signed by two officials and the allowance of cloth appropriate to the status of each servant is shown. The seniors, those of Alsop's rank, were allowed 'vii yerdes, ii peces, and vi yerdes'. Less important people such as the yeoman or assistants in the various departments, termed 'valettus', 'garcio' or 'pagetus' had only four yards. ${ }^{33}$ The total yardage was enormous; the entire household dressed in black must have presented a sombre appearance, in great contrast to the bright colours normally worn.

The names of two relatives of Alsop and of Hemingway appear in the list of the Confectionary for the first time. The staff remained throughout Mary's reign and all are noted as receiving their livery. There was one outstanding addition to the number of Mary's apothecaries-John de Soto. He had been in Mary's service when she was the Lady Mary in I55I. Perhaps because of religious difficulties de Soto had changed his name to 'Soda' for it is as John Soda that he, as citizen and grocer, was formally appointed on 4 January 1554 to be apothecary to the Queen, having already been so engaged for six months. ${ }^{34}$

So far it has not been possible to trace John Hemingway as having a royal appointment during Mary's reign. He attended on Queen Elizabeth I when she succeeded Mary in $155^{8}$ and he remained in her service for many years. Fortunately his detailed accounts kept for 'one half yere endyed at mydsomer last in ye sixth yere of her most graycous raigne' ( 1564 ) have survived. ${ }^{35}$ This was the year in which the Queen began to lose her hair rapidly and started to dress it in a new style, with a wig. They list the many and varied medicines and perfumes supplied to the Queen and to some of her household during the six months, January to June, of that year. The largest number of entries are for perfume, notably rose-water with cloves, for the Closet where the robes were kept, perfume for the Banquetting House, the Counsel Chamber, the Great Chamber, the Chapel, and for other special occasions. Rose-water, benjamin and storax were frequently sent for sweetening the robes: portraits of the Queen show her robes to have been too heavily embroidered and jewelled to allow of washing, and dry cleaning in the modern sense was unknown in Elizabeth's reign.

It was part of the apothecary's duty to supply urinals for the use of those who met in the Council Chamber: whether they were of glass or pottery is not stated but they were not expensive at $3 d$. each. Alsop had earlier charged is. for them. By the frequency with which supplies were called for, they were treated as disposable. To Mistress Marbery, one of the women of the Queen's Bed-Chamber, Hemingway sent orris powder in quantities of $2 \mathrm{lb}$. at a time, at $\mathrm{Is} .4 d$. a lb., and now and then $6 \mathrm{lb}$. of damask powder, presumably a rose scented powder, priced at $7 d$. a lb. A 'glas' of rose-water 'for the parfume panne in the private chamber' suggests that not only were the public rooms kept free of disagreeable odours but that the Queen saw to it that her private rooms were well perfumed. (The 'glas' was a measure of ro oz. to judge by the price charged when a pint was supplied. It is mentioned many times as the quantity of medicine furnished.) 


\section{Royal Apothecaries of the Tudor Period}

Each month there are several entries of 'parfumes for the Closett', sometimes a scruple of musk or fine perfume is sent to the Clerk in charge of it. When the Queen moved from Richmond to Windsor two ounces of perfume were needed to 'ayer the grete chamber' and 'the presence chamber after the makynge clene'. If she chose to go out in state an ounce of perfume was sent 'for the Lytter'. The expected arrival of the French Ambassador, M. de Gonnor, in May ${ }^{1564}$ called for more than ordinary cleansing of the rooms to be provided for him. Perfume was needed for his lodging at Sheen, for the Lord Chamberlain's chamber and for the Council Chamber where he was to be received. Whether the Queen was at Hampton Court, Richmond, Sheen or Windsor she was particularly careful to avoid unwholesome smells and they had to be masked by ample quantities of perfume: this was the case when she was in her 'standing at the triomph' or on one of her many progresses through the kingdom.

The account book of eight folios contains, in addition to the details of the supplies for the Queen, items required by some of her household. They are the more usual needs of families; for example, Mystres Asheley has camomile flowers, rose leaves, oil of roses and vinegar and she seems to have been a real 'home doctor' for there is a running account for pills, lotions, oxicrocin plaster, pectoral powders, bitter electuary, Venice turpentine, almond milk, in addition to her 'accustomed pills'. It seems there were children in the house since she gets 'anisede cumfytts, whyte sugar candy and whyte lozenges'. Her bill for six months is 3os. 2d. Mystres Marbury has plasters 'for the raignes', and is also charged $12 d$. for removing the plaster, syrop of hyssop, liquorice and diacodion. The variety of medicaments which Hemingway dispensed for her suggests that her family needed a good deal of medical attention. She is given to ordering preserved cherries ( $4 d$. oz.), sugar candy, liquorice, and confection of prunes. A glyster is charged at $3^{s .} 4^{d}$. and a dram of Mithridiatum at $8 d$. Four male members of the royal household are listed, the most important medicaments charged in their accounts being Jeans treacle, cold julep, ung. album, glysters, suppositories, at $2 d$. each, a 'certayne dyssolvatyve Locyon' and a 'restryngent glyster' which appears to have been used as a treniafuge. All the accounts were examined by both Dr. Richard Masters and Robert Huycke who sign their names at the foot of each page and verify the grand total amounting to £2I 16 s. od. at the end of June. It was paid in the following November when, in a shaky hand, Hemingway gave his acquittance: 'Receyved the sayde some of XX li XVIs of Sr John Masome Knyght treasurer of the Chamber the xii day of novembre 1564 by John Hemyngwey'.

The homely occasions of the time are evidenced by such items in the accounts as perfume provided for the christening of a child of Dr. Masters, one of the Queen's physicians and, perhaps for the guests, a box of 'dredge cumfytts', the sugar-coated sweets so often appearing in apothecaries' bills of the period. These 'cumfytts' were repeated a few times at a cost of $2 s$. or $4 s$. a box. Hemingway made up spiced wine ('ipocras with genes' ? broom), electuaries with confection of barberry, 'and divers other spices', plasters of ung(uentum) rosarum et infrigidans gallen (the cold cream devised by Galen) which were spread 


\section{Leslie G. Mattherws}

upon parchment and covered with 'sarstnett and quylted'. These were used as a cosmetic face mask. All the other plasters he made were spread on parchment, then covered with silk and an outer covering, either to protect the clothing or to keep in the warmth if applied hot.

As apothecary to the Queen, Hemingway, like his predecessor Alsop, had to undertake the preparation of what he notes as 'the bane', namely the bath. Alsop's bill, referred to above, included 'for the bayn, bagges with herbis, sponges, muske, cyvet, ut patet (as detailed), $5^{s .} 8 d$. ', and the materials for the bath were supplied only on one occasion during the six months for which we have Alsop's accounts. His bags with herbs, musk, civet, etc. would have provided a highly aromatic bath and might have been prescribed to give relief to Henry VIII's swollen legs caused by the dropsy from which he suffered in the last year of his life. Hemingway in his accounts does not list the ingredients he used in preparing the bath so that we are without information whether the 'preparacioun of the Bane' for which he charged Ios. on each occasion was for an enclosed bath in which the fumes of aromatic constituents might be expected to reduce pain or relieve tiredness or whether it was medicated or so prepared to permit subsequent applications of ointments to be more effective. By his notes the bath seems to have been stored under his direct supervision. The mention of repairs, new hoops and a new board, clearly point to a wooden bath, round or an elongated oval, made in the form of a low cask and bound with chestnut hoops, such as is depicted in drawings and miniatures of interiors of large houses of the period. It may have been an enclosed bath in which the bather sat upon a padded board to take advantage of the fumes arising from the herbs and spices provided or an ordinary medicated sitz bath. Hemingway charged Ios. for its preparation in January, again in March and in April he had it removed, set it together again and supplied a new hoop. At the end of April the bath was carried from Windsor, with 'certayne glasses of waters', to Richmond and when he set it up again, perhaps because it was damaged in transport, it required two new hoops and one new board: these cost $3^{s .} 4^{d}$. and the usual ros. was added to the bill for its preparation.

As we have seen, Hemingway was in the service of Queen Elizabeth I for some years. She continued the practice of rewarding servants of the royal household by grants of lands and in 1562 Hemingway, for his service as her apothecary (he is described as pharmacopolus), was granted a thirty-year lease, subject to his paying a fine of $£ 30$, of Santyngley Grange and all the lands thereof in Santyngley, Yorkshire. The lands had previously belonged to the monastery of St. Oswald of Nostall, Yorkshire, and had been leased by the Prior of the monastery in January 1538 for a period of years: Hemingway had therefore to wait until the lease fell in before he could take possession. It was a valuable grant, the lands having been let by the Prior for $£_{\mathrm{I}} 6 \mathrm{I} 6 s$. od. a year. ${ }^{36}$ There were many families of Hemingways in Yorkshire at this period and John Hemingway may have wished for land in his native county. Mrs. Elizabeth Marbery, mentioned in Hemingway's accounts, wife of Thomas Marbery, serjeant of the Queen's Pantry, was similarly rewarded with a grant of lands in Bedfordshire. ${ }^{37}$ 


\section{Royal Apothecaries of the Tudor Period}

It is uncertain whether Hemingway continued as Queen's apothecary until the appointment of Hugh Morgan in July $15^{8} 3^{38}$ or whether there was an intermediate appointment not yet traced. Morgan was perhaps the most outstanding of all the Tudor royal apothecaries. His appointment was made a few months before the time when he was due to become Master of the Grocers' Company and he asked to be excused from taking office then because of the duties which his service to the Queen would entail. Morgan took the office of Master later. He had long been one of the useful members of the Grocersit was he who took a party of soldiers impressed by the Grocers' Company to Greenwich, and which formed one of the City trained bands, when the Queen reviewed 2000 of them in 1559. Earlier he had been chosen as Warden of the 'Bachelors', a group of the yeomen of the Grocers, and as such was given a gown of fine puke and hood of crimson damask with the right to have the gown trimmed with the fur of marten. Morgan was trusted to be one of those to inspect drugs sold by other apothecary-members of the Grocers' Company. This was in 1564 , inspections during the previous year having been neglected because the Gity had been visited with the plague. Many drugs were found adulterated or not fit for use and the Court of the Company decided that the only thing to do with them was to burn them: this they did in the parlour fire of their Hall and a lively stench there must have been, the drugs so disposed of being rhubarb, pepper dust, wormseed, scammony cakes, 'noughty turbitt' and manna.

Apprentices were rather a problem to Morgan; one was enticed away and had to be ordered back by the Court of the Grocers: another who 'unreverently behaved himself' was sent to Bridewell, the place of correction for misdoers, and was only released and finally returned to Morgan when he kneeled before Morgan and his wife in the presence of the other apprentices and begged forgiveness.

Morgan was often asked to audit the accounts of the Company; he became a liveryman in 1563 and a Warden in 1574, serving upon the Court of Assistants for some years. There was a little trouble between him and the Company after he had entered the Queen's service: the Company objected to receiving by his hand a 'Copy' (formula) for the composition of treacle, whether a theriaca containing medicaments is not stated, that had been agreed upon by the College of Physicians of London and handed to Morgan for him to get it accepted by the apothecary section of the Grocers. The apothecaries said they would neither accept this formula 'or any other' without their Court agreed and they referred the question to the Lord Mayor for his opinion. The Court Minutes of the Company show that the quality of treacle was a constant source of trouble for many years and several members of the Company were fined for selling unsatisfactory material. ${ }^{39}$ Morgan, in a pamphlet of 1585 quoted by Wootton (I9I0) claimed that he could make 'theriacle' that compared with that from Constantinople or Venice. He lamented that 'straungers doe dayly send into England a false and naughty kind of Mithridatium and Threacle in great barrelles ... and vtter ye same ... for $3 d$. or $4 d$. a pound, to ye great hurt of Her Maiesties subjects. . . ' 40 Morgan certainly made full use of the current 


\section{Leslie G. Matthews}

materia medica for in a bill, also quoted by Wootton, he charges IIs. for a confection made with bezoar stone and unicorn's horn. ${ }^{11}$

Morgan, who was born in Bardfield, Essex, married Lucy Sybil of Farningham and Eynsford, Kent. With her he lived in his house and had his shop near Coleman Street in the City of London. ${ }^{42}$ Like other prosperous apothecaries he acquired properties whenever he could and in later life he took a substantial house and garden in Battersea, then a favourite country village on the Thames outside London. His interest in herbs developed into the growing of rare specimens. He obtained many specimens of new drugs from those who voyaged to Virginia. John Gerard in his Herball, I597, referred to Morgan as 'a curious conseruer of rare simples' and called attention to the Lote or Nettle tree, Celtis or Lotus arbor, from Italy and Eastern Europe, or from N. America, growing in Morgan's garden in the City of London, ${ }^{43}$ while John Parkinson in Paradisi in Sole Paradisus Terrestris, I629, commented upon a Judas tree, Cercis siliquastrum, which he had seen 'sometimes agoe' in Morgan's garden at Battersea. ${ }^{44}$

It was at his Battersea home that Morgan died. He was buried in St. Mary's Church there on 13 September 1613. His epitaph, on a brass now lost, and probably chosen by his cousin, Captain Robert Morgan, runs:

Hugh Morgan, late of Battersey, Esq. sleepeth here in peace.

Whom men did admire for worthful parts. To Queen Elizabeth he was Chief Pothecary till her death.

This was followed by a set of verses beginning:

And in his Science as he did Excell, In her high Favour he did always dwell. . . .

There has always been a difference of opinion about Morgan's real age. Though given as 103 and not impossible, though rare, for the period in which he lived, it is thought to have been overstated by about twenty years. Morgan's wife predeceased him and there were no children of the marriage. In his will, made 25 April 1608, of which probate was granted 25 September 1613, he refers to himself as 'Cittizen and Grocer of London' and as 'his Maiesties [James I] apothecary extraordinary'. He left sums of money to the poor of several parishes with which he or his wife had been connected, he insisted upon a series of sermons being preached within a year of his death, and he provided legacies for the purchase of rings for relatives and friends. Among the latter was named Serjeant Shyere, no doubt the George Shiers mentioned below, who was to have, amongst other things, Ios. to make him a gimbowe (a twisted ring) for his little finger. Most of the legacies were to cousins. ${ }^{46}$

Though Morgan remained as apothecary to Elizabeth during the remainder of her reign, to 1603 , Edward Hemingway was engaged as yeoman apothecary but he gave place to George Shiers who was granted the reversion of the office by the Queen herself. ${ }^{47}$ Morgan's personal service to James I was not of long duration for James, early in his reign, granted to George Shiers on 8 September 1603, the office for life of making 'all perfumes and sweet waters' for the King 


\section{Royal Apothecaries of the Tudor Period}

and Queen, at a salary of $£ 20$ a year: ${ }^{48}$ two months later he was appointed apothecary with a fee of $£ 40$ a year and 'Bouche de Court', ${ }^{40}$ the usual perquisite for senior royal servants.

What kind of men were these royal apothecaries? We know something of them from contemporary documents: they were recognized as being responsible and efficient at their work. The position that royal service afforded was greatly prized and there must have been much 'lobbying' to secure the coveted appointments. We have an example of this in George Shiers's application for the minor post of yeoman apothecary to Queen Elizabeth I before the holder, Edward Hemingway, had vacated it. Men like Thomas Pierson, Thomas Alsop and Hugh Morgan were held in such high esteem that they were elected Wardens of their Company, the Grocers; Morgan indeed becoming Master. Most of them retained their own apothecary shops in the City of London. The opportunity of supplying the Court and the household staff, in addition to providing drugs, medicines and perfumes for the monarch, made the post of royal apothecary a very profitable one, especially if the perquisites of Serjeant of the Confectionary were added. There was the additional 'Bouche de Court' which carried the right to an allowance for diet, certain clothing and lodging when in attendance on the monarch. There was too the opportunity to be of influence in Court circles and to put in a good word for one's friends when they were in difficulty or when there were offices to be filled. Presents to the royal family, perfumes or sweetmeats at the New Year, doubtless helped to make the way more pleasant. The records of the Privy Seal and others show that many of the apothecaries had extra rewards for their services, either by direct grants of lands and houses or by the chance to acquire them on favourable terms when properties were being disposed of by the Crown. Altogether their position was one of the most sought after in the kingdom.

\section{REFERENCES}

I. Calendar of Patent Rolls, Hen. VII (1484-94), p. 25I. (abb. C.P.R.).

2. Ibid., p. 252.

3. Ibid., pp. 366, 469. Ibid. (1495-1509), pp. I I 5, 136, 164, 203, 419. The properties were three messuages, one called 'the Rose upon the Hope' in Fenchurch Street, 1491; a house or messuage called 'le Belle' in Byrchyn Lane, 1494; a house and vacant piece of land in the parish of St. Benedict Sherehog, off Bucklersbury, 1497; a tenement called 'le Signe de la Dolphyn' without Bishopsgate, I498; a tenement in Berbynderlane abutting on the churchyard of St. Stephens, Walbrook, I499; and a house called 'the Lambe' in Maiden Lane, formerly a brewhouse, 1500 .

4. Letters and Papers of the Reign of Henry VIII, vol. II, pt. 2, p. 1442. (abb. L.P. Hen. VIII).

5. Chem. \&O Drugg., 1931, 114, 792-4.

6. Notes on accounts paid to the Royal Apothecaries in 1546 and 1547, ibid., I93 I, II4, 794-6.

7. L.P. Hen. VIII, vol. II, pt. 2, p. 1444 .

8. Ibid., vol. II, pt. I, p. 875 . 


\section{Leslie G. Matthews}

9. L.P. Hen. VIII, vol. II, pt. 2, p. 1467 .

I0. Ibid., vol. I, pt. I, p. 39 .

I I. Ibid., vol. Iv, pt. 3 , p. 3048 .

12. Abstracts of Inquisitiones Post Mortem for the City of London, London, 1908, pt. III, p. 107.

1 3. L.P. Hen. VIII, vol. II, pt. 2, p. I515. 14. Ibid., vol. II, pt. I, p. 244. I5. Ibid., p. 365. 16. Ibid., p. 408. 17. Ibid., vol. rv, pt. 2, p. 1571. 18. Ibid., vol. rv, pt. I, p. 54. 19. Ibid., vol. Iv, pt. I, p. 865. 20. Ibid., vol. vi, p. 247. 2 I. Ibid., vol. XII, pt. 2, p. 499. 22. Ibid., vol. XVI, p. I92. 23. Ibid., vol. XXI, pt. 2, pp. 394-9. 24. Ibid., p. 322.

25. Le Ha R Dy, W., Calendar to the Court Minute Books of the Grocers' Company, (Typescript), London, Guildhall Library, 1557. The Grocers' Company has kindly allowed this and other extracts to be taken from their books.

26. L.P. Hen. VIII, vol. Xrv, pt. 2, p. 224.

27. Abstracts Inquis. Post Mortem., op. cit., pt. 1, pp. 149-51.

28. LE HARDY, W., op. cit., I 564 .

29. L.P. Hen. VIII, vol. XXI, pt. 2, p. 331. 30. Ibid., p. 322.

31. C.P.R., Edward VI, vol. Iv, p. 168. 32. Ibid., vol. 1, p. 99.

33. 'The Ordinary of all such names ... in the Standing Rolle of the Kinges most honorable houshold.' I Mary. MS. Public Record Office, E ror, Bundle 437, No. 7 .

34. C.P.R. I Mary, pt. xn, p. 3 I 7.

35. British Museum. Sloane MS. $5017{ }^{*}(4)$.

36. C.P.R. Eliz., vol. II, pp. 245-6.

37. Ibid., pp. 289-9o.

38. C.P.R., R. R. Elizabeth $X X V^{\circ}$, sexta pars, fo. I Ib. MS. Public Record Office.

39. LE HARDY, W., op. cit., I559, 1563,1574 and 1584 .

40. Wootton, A. C., Chronicles of Pharmacy, London, I9ro, vol. II, pp. 44-5.

41. Ibid., vol. I, p. 296.

42. Brad F ORD, C. A., Hugh Morgan, Queen Elizabeth's Apothecary, London, 1939.

43. The Herball or Generall Historie of Plantes, Thomas Johnson's edition, London, 1633, p. 1493.

44. London, 1629, p. 437.

45. BRADFORD, C. A., op. cit.

46. Prerogative Court of Canterbury Wills, 84 Capell. MS. Somerset House.

47. Cal. State Papers, Domestic, 1598-160r, p. 219.

48. C.P.R., I Jac. I, tercia pars, fo. 4. MS. Public Record Office.

49. Ibid., pars xxi, fo. $3^{8 \mathrm{~b} \text {. }}$

Note. The unpublished Crown Copyright material in the Public Record Office has been reproduced by permission of the Controller of H.M. Stationery Office. Unpublished material in the British Museum has been used by permission of the Trustees of the Museum. 